\title{
$\widehat{A}$ Madridge \\ madridge Journal of Dermatology \& Research \\ interconnecting Scientific World
}

Case Report

Open Access

\section{Treatment of Recalcitrant Chronic GVHD Ulcers with Combined Silver Collagen Matrix and Silver Foam Dressings}

\author{
Timothy H Almazan and Jae Yeon Jung* \\ Division of Dermatology, City of Hope Comprehensive Cancer Center, USA
}

\section{Article Info}

\author{
*Corresponding author: \\ Jae Yeon Jung \\ Division of Dermatology \\ City of Hope Comprehensive Cancer Center \\ 1500 East Duarte Road \\ Duarte, CA 91010 \\ USA \\ Tel: 626-256-4673, ext: 65621 \\ E-mail: jjung@coh.org
}

\section{Received: August 6, 2016 \\ Accepted: October 24, 2016 \\ Published: October 27, 2016}

Citation: Almazan TH, Jung JY. Treatment of Recalcitrant Chronic GVHD Ulcers with Combined Silver Collagen Matrix and Silver Foam Dressings. Madridge J Dermatol Res. 2016; 1(1): 11-17.

doi: $10.18689 / \mathrm{mjdr}-1000103$

\section{Copyright: (c) 2016 The Author(s). This work is licensed under a Creative Commons Attribution 4.0 International License, which permits unrestricted use, distribution, and reproduction in any medium, provided the original work is properly cited.}

Published by Madridge Publishers

\begin{abstract}
Importance: Chronic ulcers in patients with sclerotic graft versus host disease are recalcitrant to treatment and treatment options are limited. These patients are immunosuppressed and frequently hospitalized due to infections. Systemic antibiotics are generally ineffective in eradicating colonized bacteria that are often multidrug resistant and local wound care is critical in the management of these difficult ulcers. We present three patients who developed rapid and sustained improvement using a combination of silver collagen matrix and silver sponge dressings with compression.
\end{abstract}

Observations: Three patients with chronic lower extremity ulcers due to sclerotic chronic graft versus host disease presented for wound care in our Dermatology clinic. The wounds were chronically colonized with multidrug resistant bacteria and these patients were frequently hospitalized due to infection and pain. Multiple topical agents were unsuccessful in treating these recalcitrant and morbid ulcerations. Significant improvement was obtained with a combination of silver collagen and silver sponge dressings.

Conclusions and Relevance: There is a paucity of published data regarding the treatment options for chronic graft versus host ulcers. These ulcers are challenging due to immunosuppressive regimens and chronic bacterial colonization and recurrent infections. We report three cases treated successfully with a combination of silver collagen matrix and silver sponge dressings.

Keywords: Recalcitrant Chronic GVHD Ulcers; Silver Collagen Matrix; Silver Foam Dressings; Sclerotic Graft vs Host Disease.

Abbreviations: GVHD: Graft Versus Host Disease; TNF: Tumor Necrosis Factor; UV A:
Ultraviolent A; UV B: Ultraviolent B; IVIG: Intravenous Immunoglobulin; CGVHD: Chronic
Graft Versus Host Disease; CSMD: Collagen Silver Matrix Dressing; SSD: Silver Sponge
Dressing; HLA: Human Leukocyte Antigen; BSA: Body Surface Area; Mg: Milligram; STSG:
Split Thickness Skin Graft; Cx: Culture; Ami: Amikacin; Tob: Tobramycin; Czn: Cefazolin;
Cfx: Ceftriaxone; Cef: Cefepime; Amx: Amoxicillin; Amp: Ampicillin; Ctx: Cefoxitin; Caz:
Ceftazidime; Cip: Ciprofloxacin; Cli: Clindamycin; Ery: Erythromycin; Gen: Gentamicin;
Ipm: Imipenem; Lvx: Levofloxacin; Mem: Meropenem; Oxa: Oxacillin; Pen: Penicillin; Tzp:
Piperacillin-Tazobactam; Tet: Tetracycline; Sxt: Trimethoprim-Sulfamethoxazole; Van:
Vancomycin. 


\section{Introduction}

Chronic graft versus host disease (GVHD) is a significant cause of morbidity and mortality following allogeneic hematopoetic stem cell transplantation. Approximately 50\% of allogeneic transplant patients develop chronic GVHD. The skin is the most commonly affected organ (70-80\%). Oral and genital mucosa, lung, liver, eye, and joint involvement are also common [1]. Of the patients with chronic cutaneous GVHD, sclerotic disease is one of the most severe manifestations and is associated with poor quality of life, functional status, and higher mortality [2]. Despite advances in transplantation methods, chronic GVHD incidence and prevalence is rising due to the increasing numbers of allogeneic transplantations, increasing use of unrelated donors, and peripheral blood transplants, as well as decreasing early transplant related mortality. These parameters predict an expanding population of long-term survivors with increasingly morbid disease [3].

The pathogenesis of chronic GVHD is poorly understood and its treatment is challenging. The first line therapy is corticosteroids but this treatment cannot be maintained chronically due to significant side effects. In patients who are steroid refractory, there is no second line therapy that is proven to improve survival. Currently available second-line agents such as cyclosporine, tacrolimus, sirolimus, extracorporeal photophoresis, mycophenolate mofetil, TNF inhibitors, and rituximab are used based on clinician preference, the side effect profile, and the patient's prior response to therapy. No good randomized, controlled trial data exists to guide second-line therapy, and existing studies are difficult to interpret due to the complexities of grading response [4].

More than 4000 marrow transplants are performed annually in the United States, and of these, nearly half are complicated by clinically significant GVHD [5]. The incidence of sclerotic disease is estimated at $20 \%$ of patients undergoing allogeneic hematopoetic transplantation [6]. Though a number of treatments have been used for cutaneous CGVHD including topical and systemic steroids, extracorporeal photophoresis, UV A or UV B phototherpy, IVIG, and rituximab, little data exists regarding treatment specifically for CGVHDrelated skin ulcers [7]. The largest series published includes 25 patients with an incidence of $0.56 \%$ [8].

There are few guidelines for the treatment of chronic ulcers from chronic GVHD. Hematologists are reluctant to increase systemic immunosuppression due to the risk of infection. Although these patients are frequently admitted for intravenous antibiotics, these wounds are chronically colonized, often with multidrug resistant bacteria, and infection cannot be eradicated. We report successful treatment of three patients using a combination of collagen silver matrix dressing (CSMD), silver sponge dressing (SSD), and local compression.

\section{Materials}

Our choice of dressing materials was determined by the availability at our institution. We do not have any relevant financial disclosures and do not endorse the use of any specific brand of dressing. The dressings used in our patients include: silver collagen matrix dressing (Puracol ${ }^{\circledR}$ Plus AG+ Collagen Dressing, Medline Industries, Mundelein, Illinois), silver sponge dressing (Mepilex ${ }^{\circledR}$ AG, Mölnlycke Health Care, Göteborg, Sweden); self adherent compression dressing (Coban ${ }^{\mathrm{TM}}, 3 \mathrm{M}^{\mathrm{T} \mathrm{M}}$, Saint Paul, Minnesota); 3\% bismuth tribromophenate petrolatum gauze (Xeroform, DeRoyal ${ }^{\circledR}$, Powell, Tennessee); collagenase ointment (Santyl ${ }^{\circledR}$, Smith and Nephew, London, United Kingdom), and gentian violet sponge dressing (Hydrofera ${ }^{\circledR}$ blue, Hollister Wound Care, Libertyville, Illinois).

\section{Cases}

Patient 1 is a man in his 40 s with a history of AML treated with allogeneic stem cell transplantation from his HLAmatched sibling 9 years prior to presentation. He was admitted to our hospital with right lower extremity ulcerations. Cultures at that time demonstrated pan-sensitive Pseudomonas aeruginosa. He was treated with vancomycin, ceftazidime and metronidazole. At his initial presentation to the dermatology clinic, his foot was erythematous and there was a green-yellow necrotic base in the ulcers (figure $1 A$ ). His sclerotic GVHD was extensive, involving over 50\% BSA with restricted range of motion in his wrist and ankles. The skin over his distal lower extremities demonstrated hide bound sclerotic plaques and he was unable to move his toes. He had poorly controlled type 2 diabetes with a hemoglobin A1c of $9.6 \%$. He was on sirolimus and mycophenolate mofetil for his chronic GVHD. He had been treated with negative pressure wound therapy without significant improvement. Local therapy was initiated with clobetasol $0.05 \%$ ointment, silver sponge dressings and compression. After 2 months without improvement, he was switched to collagenase ointment and 3\% bismuth tribromophenate petrolatum gauze. No improvement was noted after an additional 2 months. He was then switched to a combination dressing consisting of collagen silver matrix, silver sponge dressing and compression. At each visit, the necrotic base was gently debrided with a sharp, disposable curette, the CSMD was cut to fit in the ulcer base, and the SSD was applied over it. A self-adherent wrap was used to hold the dressing in place and provide compression. The patient was instructed to change the dressing every 3-4 days and was seen in clinic once a week. After 2 months of treatment, the ulcers had granulated and the surface started to re-epithelialize (figure 1B). His pain also significantly improved. 
Figure 1 (title). Chronic graft-versus-host disease related lower extremity skin ulcerations.

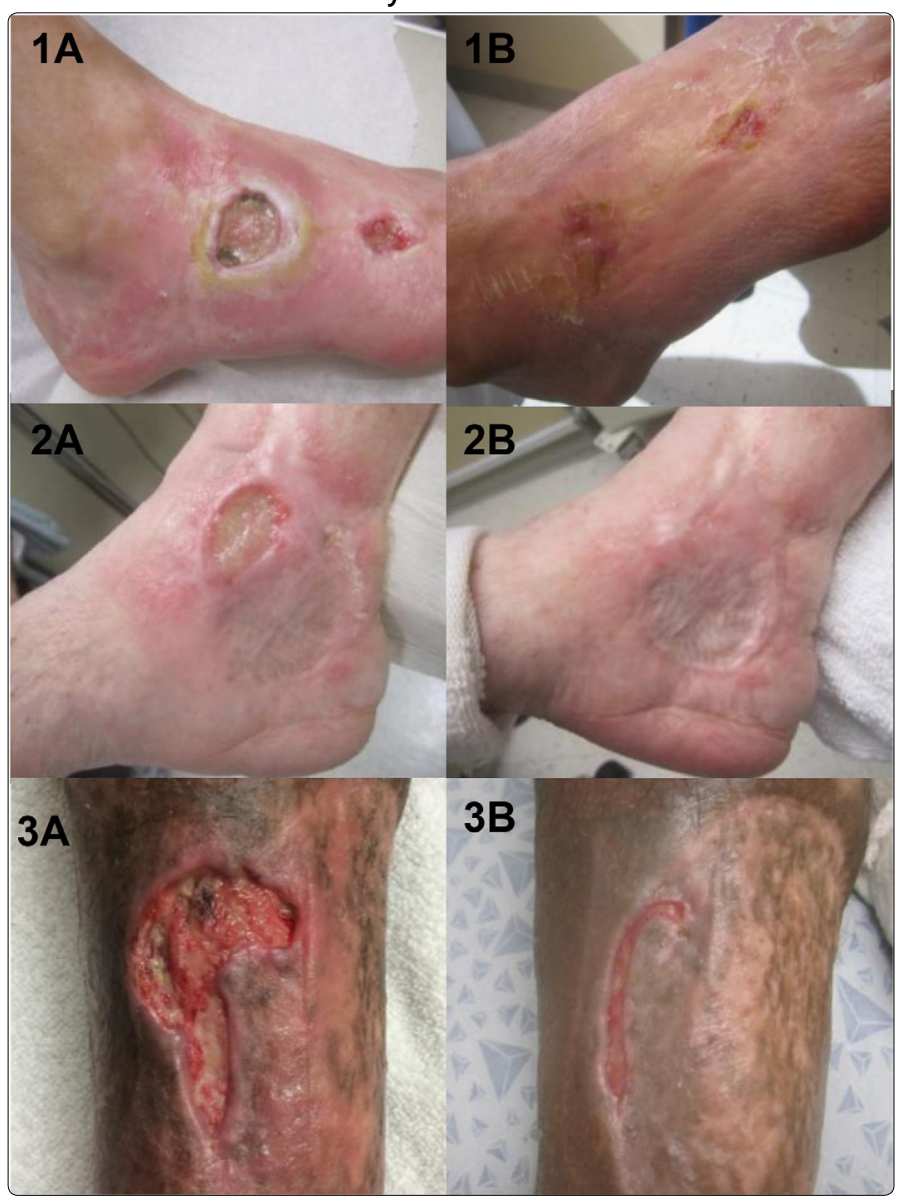

Figure 1 (legend): Cutaneous graft-versus-host disease affecting the right lower extremity, with necrotic-based ulcerations of the anterior foot and sclerotic changes of the surrounding skin (1A). Improvement of ulcers following 2 months of treatment using the described treatment regimen and eventual complete reepithelialization of ulcer following 2 months of treatment (1B). GVHD-related ulcer of the right medial malleolus, adjacent to prior split thickness skin graft (2A). Evolution of ulcer improvement after three months using collagen silver matrix dressing, silver sponge dressing, and local compression; skin closure was achieved after 3 months (2B).Severe, sclerotic GVHD of the right lower extremity with irregularly shaped, well-demarcated ulcer extending to the fascia (3A). Near complete healing of the ulcer occurred after 4 months of CSMD, SSD, and compression therapy (3B).

Patient 2 is a woman in her 70s with a history of myelodysplastic syndrome and subsequent allogeneic hematopoietic transplant from her HLA-matched sibling 4 years prior to presentation. She had sclerotic GVHD of the skin affecting over $50 \%$ BSA and recurrent ulceration of her right medial malleolous that was treated previously by split thickness skin graft. She also had chronic lower extremity edema with recurrent hospitalizations for lower extremity cellulitis. She also had poorly controlled diabetes with a hemoglobin A1c of $8.1 \%$. Immunosuppressive medications included tacrolimus, sirolimus and prednisone (20 mg daily). Additionally, photopheresis was attempted, but was held due to neutropenia. She presented with a new ulceration that developed adjacent to her previously well-healed STSG on her right medial ankle (figure $2 \mathrm{~A}$ ) that had been slowly enlarging for 10 months. She had numerous admissions for infection and pain control and cultures demonstrated methicillinresistant Staphylococcus aureus and Morganella morganii. She had been treated with collagenase ointment and gentian violet impregnated dressing. The patient noted an enlarging wound with increasing pain despite this treatment. Local therapy was initiated with compression wraps, topical $1 \%$ clindamycin, $0.05 \%$ clobetasol ointment and silver sponge dressings; these were unsuccessful in promoting ulcer regression. Treatment was changed to include the CSMD and SSD with compression and resulted in gradual improvement and eventual closure of the ulcer after 3 months (figures 2B).

Figure 2 (title). Bacterial isolates from chronic ulcers in patients with sclerotic chronic GVHD, resulting in prolonged hospitalizations.

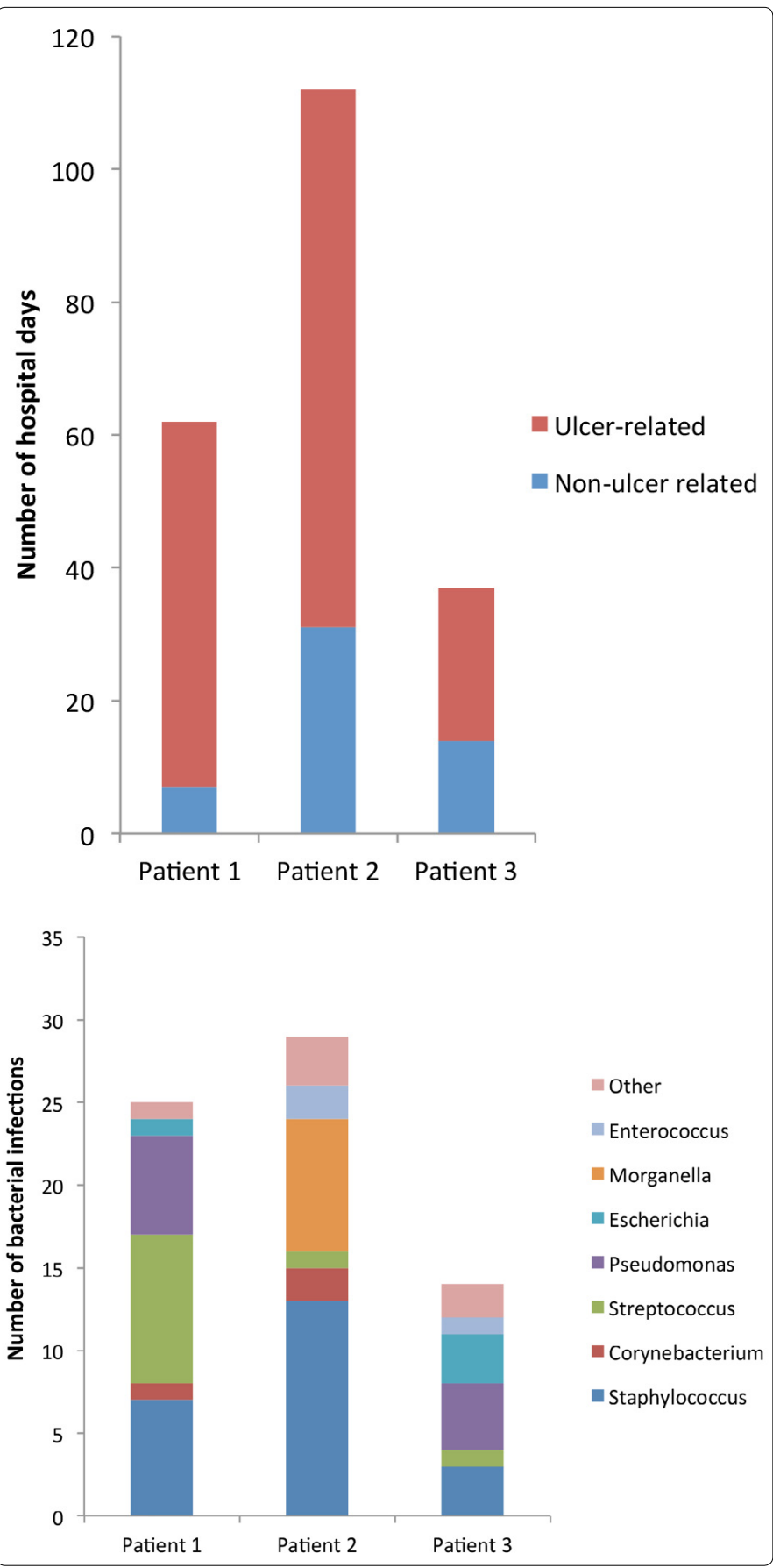

Figure 2 (legend): Due to multi-drug resistant superinfections, chronic GVHD-related ulcers result in frequent repeat hospitalizations for patients. 
Patient 3 is a man in his 30 s with a history of AML who received a hematopoietic cell transplant from a matched unrelated donor 5 years prior to presentation. He developed sclerotic GVHD of the skin that was largely confined to his right lower extremity. He developed a lower extremity ulceration that was treated with split thickness skin graft (figure 3A). Immunosuppressive regimen included prednisone, tacrolimus and sirolimus. Failed treatments included collagenase ointment and gentian violet containing dressing. We initiated treatment with CSMD, SSD and compression. The dressings were changed every $3-4$ days and the wound base was debrided every 1-2 weeks using a disposable sharp $5 \mathrm{~mm}$ curette. The ulcer was noted to heal to near complete resolution over the course of 4 months (figure 3B).

\section{Discussion}

The treatment of sclerotic disease is particularly difficult when chronic ulcerations develop because the immunosuppressive medications that are used to treat the GVHD contribute to the recurrent infections common to these patients. Although the exact mechanisms are unknown, inflammation and fibrosis are thought to play a key role in the etiology of chronic GVHD related ulcer formation. While only $10 \%$ of patients with cGVHD present with sclerotic skin, nearly all patients with cGVHD-related ulcers develop them on areas of prior sclerosis $[9,10]$. Ulcers are usually preceded by bullous lesions, where skin detachment between the epidermis and the dermis facilitates erosion and provides a highly prone substrate for ulcers to form following the slightest trauma. Additionally, skin edema, a non-specific finding associated with CGVHD, may lead to inappropriate endothelial activation and exacerbation of the dermal-epidermal detachment. Once erosions are formed, a background of sclerotic tissue along with local lymphatic and microvascular derangement may lead to both ulcer enlargement and poor wound healing.

All patients described in this case series developed ulcerated lesions of the lower extremities. Two patients initially responded well to split thickness grafting, however, both developed subsequent ulcerations adjacent to the skin graft. Patient 1 and 2 were hospitalized 3 times for ulcer-related infection and patient 3 was hospitalized 8 times (table 1). These patients had a total of 211 hospital days in our electronic medical record and $75 \%$ (159) of those days were ulcerrelated (Figure 4). With increased costs associated with health care, outpatient management of these chronic ulcers will be increasingly desirable [11].
Table 1: Chronic GVHD and ulcer-related hospital admissions

\begin{tabular}{|c|c|c|c|}
\hline \multicolumn{4}{|r|}{ Patient 1} \\
\hline Admission & Discharge & $\begin{array}{l}\text { GHVD- } \\
\text { ulcer } \\
\text { related? }\end{array}$ & Notable events \\
\hline $11 / 16 / 09$ & $12 / 2009$ & YES & $\begin{array}{l}\text { Admitted for painful, infected right foot } \\
\text { ulcers with surrounding cellulitis. Wound } \\
\text { cultures grew Pseudomonas and } \\
\text { Enterococcus. Treated with cefazolin, then } \\
\text { ceftazidime plus linezolid. Discharged home } \\
\text { on amoxicillin/clavulanic acid and linezolid. } \\
\text { Noted to have low IgG levels and received } \\
\text { IVIG while in the hospital }\end{array}$ \\
\hline $1 / 20 / 10$ & $2 / 2010$ & YES & $\begin{array}{l}\text { Admitted for left foot cellulitis/infected } \\
\text { wounds. Wound cx grew Pseudomonas. MRI } \\
\text { of left foot negative for osteomyelitis. } \\
\text { Receivednegative-pressure wound therapy } \\
\text { on left foot }\end{array}$ \\
\hline $3 / 17 / 11$ & $3 / 2011$ & YES & $\begin{array}{l}\text { Admitted for infected right foot ulcer. } \\
\text { Received vancomycin, ceftazidime, and } \\
\text { metronidazole. Received debridement and } \\
\text { negative-pressure wound therapy on right } \\
\text { foot. Received IVIG in the hospital }\end{array}$ \\
\hline $3 / 14 / 12$ & $3 / 2012$ & No & $\begin{array}{l}\text { Admitted for bilateral hand cellulitis and } \\
\text { hand swelling. Blood cultures were negative. } \\
\text { Received inpatient vancomycin and } \\
\text { meropenem. Discharged on oral levofloxacin }\end{array}$ \\
\hline \multicolumn{4}{|r|}{ Patient 2} \\
\hline Admission & Discharge & $\begin{array}{l}\text { GHVD- } \\
\text { ulcer } \\
\text { related? }\end{array}$ & Notable events \\
\hline 10/12/09 & $10 / 2009$ & No & $\begin{array}{l}\text { Worsening general skin related GVHD. } \\
\text { Received IV methylprednisolone and } \\
\text { photophresis x4 }\end{array}$ \\
\hline $6 / 4 / 12$ & $6 / 2012$ & YES & $\begin{array}{l}\text { Right lower extremity infected ulcer with } \\
\text { cellulitis. Wound culture grew morganella, } \\
\text { staphylococcus aureus, enterobacter, } \\
\text { streptococcus viridans. Treated with } \\
\text { vancomycin and meropenem. Discharged on } \\
\text { vancomycin and levofloxacin }\end{array}$ \\
\hline $8 / 4 / 12$ & $8 / 2012$ & YES & $\begin{array}{l}\text { Fever to } 102^{\circ} \text { F. Source thought likely } \\
\text { secondary to infected ulcer. Wound culture } \\
\text { grew Morganella. Treated with ceftazidime }\end{array}$ \\
\hline $8 / 15 / 12$ & $8 / 2012$ & YES & $\begin{array}{l}\text { Fever to } 102^{\circ} \mathrm{F} \text {, with chills. Source though } \\
\text { secondary to ulcer. Treated with vancomycin } \\
\text { and meropenem }\end{array}$ \\
\hline $10 / 11 / 12$ & $10 / 2012$ & YES & $\begin{array}{l}\text { Infected, necrotic lower extremity ulcer. } \\
\text { Treated with vancomycin and meropenem. } \\
\text { Discharged on vancomycin }\end{array}$ \\
\hline $11 / 30 / 12$ & $12 / 2012$ & No & $\begin{array}{l}\text { Generalized weakness, dehydration, } \\
\text { hyperkalemia. Patient improved with fluids }\end{array}$ \\
\hline $1 / 29 / 13$ & $2 / 2013$ & YES & $\begin{array}{l}\text { Right ankle wound infection. Treated with } \\
\text { imipenem and vancomycin. MRI of right foot } \\
\text { negative for osteomyelitis. No incision and } \\
\text { drainage was necessary per wound consult } \\
\text { team. Wound culture grew Staphylococcus } \\
\text { aureus and Morganella }\end{array}$ \\
\hline $4 / 16 / 13$ & $4 / 2013$ & YES & $\begin{array}{l}\text { Planned admission for split-thickness skin } \\
\text { graft to right medial malleolus with } \\
\text { placement of post-op wound vac. Wound } \\
\text { vac was removed prior to discharge }\end{array}$ \\
\hline $10 / 7 / 13$ & $10 / 2013$ & YES & $\begin{array}{l}\text { Right ankle ulcer and cellulitis. Wound } \\
\text { culture grew MRSA and gram negative rods. } \\
\text { Treated with vancomycin and meropenem. } \\
\text { Received bedside wound debridement }\end{array}$ \\
\hline $1 / 1 / 14$ & $1 / 2014$ & No & $\begin{array}{l}\text { Fevers, rigors. Blood cultures negative. } \\
\text { Infectious source unclear. Received } \\
\text { azithromycin and ceftazidime. Hospital } \\
\text { course complicated by transient ischemic } \\
\text { attack with negative neurology work-up } \\
\text { (including negative MRI) }\end{array}$ \\
\hline
\end{tabular}




\begin{tabular}{|l|l|l|l|}
\hline $11 / 27 / 14$ & $12 / 2014$ & YES & $\begin{array}{l}\text { Left dorsal foot ulceration with wound } \\
\text { culture growing MRSA. Treated with } \\
\text { vancomycin. Blood cultures positive for } \\
\text { Staph epidermidis }\end{array}$ \\
\hline $12 / 19 / 14$ & $12 / 2014$ & No & $\begin{array}{l}\text { Intractable hip pain and lower extremity } \\
\text { weakness. Imaging negative for acute hip } \\
\text { fracture. Patient treated with occupational } \\
\text { and physical therapy }\end{array}$ \\
\hline
\end{tabular}

Table continued

\begin{tabular}{|c|c|c|c|}
\hline \multicolumn{4}{|r|}{ Patient 3} \\
\hline Admission & Discharge & $\begin{array}{l}\text { GHVD- } \\
\text { ulcer } \\
\text { related? }\end{array}$ & Notable events \\
\hline 10/5/09 & $10 / 2009$ & No & $\begin{array}{l}\text { Admitted for nausea, vomiting, abdominal } \\
\text { pain, and fevers in the setting of AML } \\
\text { history. Treated with ceftadizime. Blood and } \\
\text { stool cultures negative }\end{array}$ \\
\hline $8 / 10 / 10$ & $8 / 2010$ & No & $\begin{array}{l}\text { Admitted for fevers and cough. Chest x-ray } \\
\text { did not show infiltrates. Blood cultures were } \\
\text { negative. Improved on levofloxacin }\end{array}$ \\
\hline 10/13/10 & 10/2010 & No & $\begin{array}{l}\text { Admitted for avascular necrosis of bilateral } \\
\text { patella necessitating bone grafting. Hospital } \\
\text { course complicated by pulmonary embolism. } \\
\text { Anticoagulation initiated in the intensive } \\
\text { care unit. Discharged on enoxaparin }\end{array}$ \\
\hline 9/5/12 & $9 / 2012$ & YES & $\begin{array}{l}\text { Admitted for superinfected right calf ulcer. } \\
\text { Treated with vancomycin and meropenem. } \\
\text { MRI of the calf negative for abscess. Cultures } \\
\text { grew coagulase negative staphylococcos } \\
\text { and moderate gram negative rods. } \\
\text { Discharged with PICC line on ceftazidime } \\
\text { and vancomyin }\end{array}$ \\
\hline $12 / 5 / 12$ & $12 / 2012$ & YES & $\begin{array}{l}\text { Admitted for wound infection of right calf, } \\
\text { necessitating IV antibiotics and surgical } \\
\text { debridement. Febrile to } 100.2^{\circ} \mathrm{F} \text {. Received } \\
\text { tobramycin and ceftazidime. Wound culture } \\
\text { grew pseudomonas. Received wound vac on } \\
\text { right calf }\end{array}$ \\
\hline $3 / 5 / 13$ & $3 / 2013$ & YES & $\begin{array}{l}\text { Planned admission for split thickness skin } \\
\text { graft from right thigh to right ankle ulcer } \\
\text { with subsequent wound vac placement }\end{array}$ \\
\hline
\end{tabular}

All three patients developed persistent colonization and recurrent super-infection of the ulcers (Table 2). Cultures of the right lower extremity ulcer from Patient 1 demonstrated Streptococcus agalectiae resistant to erythromycin on 3 different cultures spanning nearly 2 years (2013-2015). He also developed colonization of multidrug resistant MRSA with an identical drug resistance pattern. Patient 2 had multi-drug resistant Morganella morganii cultured 8 times and multidrug resistant MRSA cultured 10 times over a 3-year period. The sensitivities were nearly identical suggesting chronic colonization and the formation of recalcitrant bacterial biofilms [12] (Table 1). Cultures are underutilized and too often, empiric antibiotic use leads to inappropriate treatment and contributes to antibiotic resistance [13]. The most prevalent species in our patients were Staphylococcus, Streptococcus, Pseudomonas, Escherichia, and Morganella which comprised over $80 \%$ of the isolates in our patients (Figure 2).
Table 2: Bacterial cultures and sensitivities in chronic GVHD ulcers

\begin{tabular}{|c|c|c|c|}
\hline \multicolumn{4}{|c|}{ Patient 1} \\
\hline $\begin{array}{l}\text { Date of } \\
c x\end{array}$ & Culture results & Sensitive & Resistant \\
\hline \multirow{2}{*}{$1 / 22 / 10$} & few Pseudomonas & $\begin{array}{l}\text { cip, gen, ipm, Ivx, tob; } \\
\text { intermediate sensitivity to caz }\end{array}$ & None \\
\hline & $\begin{array}{l}\text { rare coagulase negative } \\
\text { Staphylococcus }\end{array}$ & None & None \\
\hline \multirow{2}{*}{$1 / 22 / 10$} & $\begin{array}{l}\text { few Pseudomonas } \\
\text { aeruginosa }\end{array}$ & $\begin{array}{l}\text { cip, gen, ipm, lvx, tob; } \\
\text { intermediate sensitivity to caz }\end{array}$ & None \\
\hline & $\begin{array}{l}\text { few coagulase negative } \\
\text { Staphylococcus }\end{array}$ & None & None \\
\hline \multirow{4}{*}{$3 / 17 / 11$} & few Escherichia coli & $\begin{array}{l}\text { ami, czn, fox, caz, gen, ipm, } \\
\text { Ivx, mem, tzp, tob }\end{array}$ & amp, sxt \\
\hline & $\begin{array}{l}\text { moderate Corynebacterium } \\
\text { species (not group JK) }\end{array}$ & None & None \\
\hline & $\begin{array}{l}\text { few Streptococcus agalectiae } \\
\text { (sero group B) }\end{array}$ & None & None \\
\hline & $\begin{array}{l}\text { light Haemophilus } \\
\text { parainfluenzae }\end{array}$ & None & None \\
\hline \multirow{4}{*}{$8 / 29 / 13$} & $\begin{array}{l}\text { light } P \text { seudomonas } \\
\text { aeruginosa }\end{array}$ & $\begin{array}{l}\text { ami, caz, cip, ipm, Ivx, mem, } \\
\text { tob }\end{array}$ & None \\
\hline & light Staphylococcus aureus & $\begin{array}{l}\text { cli, cip, ery, gen, lvx, oxa, } \\
\text { tet, sxt, van }\end{array}$ & pen \\
\hline & $\begin{array}{l}\text { light Streptococcus } \\
\text { agalectiae (sero group B) }\end{array}$ & amp, cfx, cli Ivx, pen, van & ery \\
\hline & light viridans Strep & None & None \\
\hline \multirow{2}{*}{$9 / 27 / 13$} & $\begin{array}{l}\text { few Pseudomonas } \\
\text { aeruginosa }\end{array}$ & $\begin{array}{l}\text { ami, caz, cip, ipm, Ivx, mem, } \\
\text { tob }\end{array}$ & None \\
\hline & $\begin{array}{l}\text { light Streptococcus } \\
\text { agalectiae (sero group B) }\end{array}$ & ami, cfx, cli, Ivx, pen, van & ery \\
\hline $1 / 20 / 14$ & $\begin{array}{l}\text { few Pseudomonas } \\
\text { aeruginosa }\end{array}$ & $\begin{array}{l}\text { ami, caz, cip, ipm, mem, } \\
\text { tob; intermediate sensitivity } \\
\text { to Ivx }\end{array}$ & None \\
\hline \multirow{3}{*}{$4 / 18 / 14$} & $\begin{array}{l}\text { rare Streptococcus agalectiae } \\
\text { (sero group B) }\end{array}$ & None & None \\
\hline & few viridans Strep & None & None \\
\hline & $\begin{array}{l}\text { few coagulase negative } \\
\text { Staphylococcus }\end{array}$ & None & None \\
\hline \multirow{2}{*}{$7 / 21 / 14$} & $\begin{array}{l}\text { few Streptococcus agalectiae } \\
\text { (sero group B) }\end{array}$ & amp, cfx, cli, lvx, pcn, van & ery \\
\hline & $\begin{array}{l}\text { coagulase negative } \\
\text { Staphylococcus }\end{array}$ & None & None \\
\hline $7 / 14 / 14$ & $\begin{array}{l}\text { rare Pseudomonas } \\
\text { aeruginosa }\end{array}$ & $\begin{array}{l}\text { ami, caz, cip, ipm, Ivx, mem, } \\
\text { tob, cef }\end{array}$ & None \\
\hline \multirow[b]{2}{*}{$10 / 23 / 14$} & $\begin{array}{l}\text { moderate Streptococcus } \\
\text { agalectiae (sero group B) }\end{array}$ & amp, cfx, cli, lvx, pen, van & ery \\
\hline & $\begin{array}{l}\text { moderate Staphylococcus } \\
\text { aureus (MRSA) }\end{array}$ & cli, gen, tet, sxt, van & $\begin{array}{l}\text { cip, ery, } \\
\text { Ivx, oxa, } \\
\text { pen }\end{array}$ \\
\hline \multirow[t]{2}{*}{ 2/9/15 } & $\begin{array}{l}\text { few Staphylococcus aureus } \\
\text { (MRSA) }\end{array}$ & cli, gen, tet, sxt, van & $\begin{array}{l}\text { cip, ery, } \\
\text { Ivx, oxa, } \\
\text { pen }\end{array}$ \\
\hline & $\begin{array}{l}\text { Streptococcus agalectiae } \\
\text { (sero group B) }\end{array}$ & amp, cfx, cli, Ivx, pen, van & ery \\
\hline
\end{tabular}

Table continued

\begin{tabular}{|c|c|c|c|}
\hline \multicolumn{4}{|c|}{ Patient 2} \\
\hline $\begin{array}{l}\text { Date of } \\
\text { cx }\end{array}$ & Culture results & Sensitive & Resistant \\
\hline \multirow{4}{*}{ 6/4/2010 } & $\begin{array}{l}\text { moderate Morganella } \\
\text { morganii }\end{array}$ & $\begin{array}{l}\text { ami, fox, caz, gen, mem, } \\
\text { txp, tob; intermediate } \\
\text { sensitivity to Ivx }\end{array}$ & $\begin{array}{l}\text { amp, czn, } \\
\text { sxt }\end{array}$ \\
\hline & $\begin{array}{l}\text { moderate Staphylococcus } \\
\text { aureus (MRSA) }\end{array}$ & gen, tet, van & $\begin{array}{l}\text { cli, cip, ery, } \\
\text { Ivx, oxa, } \\
\text { pen, sxt }\end{array}$ \\
\hline & Enterobacter cloacae & $\begin{array}{l}\text { ami, caz, gen, ipm, Ivx, } \\
\text { mem, tzp, tob, sxt }\end{array}$ & czn, fox \\
\hline & viridans Strep & None & None \\
\hline
\end{tabular}




\begin{tabular}{|c|c|c|c|}
\hline \multirow{3}{*}{$8 / 15 / 12$} & $\begin{array}{l}\text { few Staphylococcus aureus } \\
\text { (MRSA) }\end{array}$ & gen, tet, sxt, van & $\begin{array}{l}\text { cli, cip, } \\
\text { ery, lev, } \\
\text { oxa, pen }\end{array}$ \\
\hline & $\begin{array}{l}\text { few coagulase negative } \\
\text { Staphylococcus }\end{array}$ & None & None \\
\hline & few Corynebacterium species & None & None \\
\hline \multirow[b]{2}{*}{$8 / 3 / 12$} & light Morganella morganii & $\begin{array}{l}\text { ami, caz, gen, mem, tzp, } \\
\text { tob; intermediate sensitivity } \\
\text { to fox }\end{array}$ & $\begin{array}{l}\text { amp, czn, } \\
\text { lvx, sxt }\end{array}$ \\
\hline & $\begin{array}{l}\text { light Staphylococcus aureus } \\
\text { (MRSA) }\end{array}$ & gen, tet, van & $\begin{array}{l}\text { cli, cip, } \\
\text { ery, Ivx, } \\
\text { oxa, pen, } \\
\text { sxt }\end{array}$ \\
\hline \multirow[t]{3}{*}{$10 / 11 / 12$} & $\begin{array}{l}\text { Staphylococcus aureus } \\
\text { (MRSA) }\end{array}$ & gen, tet, van & $\begin{array}{l}\text { cli, cip, } \\
\text { ery, Ivx, } \\
\text { oxa, pen, } \\
\text { sxt }\end{array}$ \\
\hline & few Morganella morganii & $\begin{array}{l}\text { ami, czn, fox, caz, gen, } \\
\text { mem, tzp, tob }\end{array}$ & $\begin{array}{l}\text { amp, Ivx, } \\
\text { sxt }\end{array}$ \\
\hline & $\begin{array}{l}\text { rare Citrobacter freundii } \\
\text { complex }\end{array}$ & $\begin{array}{l}\text { ami, caz, gen, ipm, lvx, } \\
\text { mem, tzp, tob, sxt }\end{array}$ & czn, fox \\
\hline \multirow[t]{2}{*}{$12 / 12 / 12$} & $\begin{array}{l}\text { heavy Staphylococcus aureus } \\
\text { (MRSA) }\end{array}$ & van, tet, gen & $\begin{array}{l}\text { cli, cip, } \\
\text { ery, Ivx, } \\
\text { oxa, pen, } \\
\text { sxt }\end{array}$ \\
\hline & $\begin{array}{l}\text { moderate Morganella } \\
\text { morganii }\end{array}$ & $\begin{array}{l}\text { ami, caz, ipm, mem, tzp, } \\
\text { tob }\end{array}$ & $\begin{array}{l}\text { czn, Ivx, } \\
\text { sxt }\end{array}$ \\
\hline \multirow[b]{2}{*}{$1 / 29 / 13$} & $\begin{array}{l}\text { moderate Morganella } \\
\text { morganii }\end{array}$ & $\begin{array}{l}\text { ami, caz, ipm, mem, tzp, } \\
\text { tob }\end{array}$ & $\begin{array}{l}\text { Czn, Ivx, } \\
\text { sxt }\end{array}$ \\
\hline & $\begin{array}{l}\text { moderate Staphylococcus } \\
\text { aureus (MRSA) }\end{array}$ & gen, tet, van & $\begin{array}{l}\text { cli, cip, } \\
\text { ery, Ivx, } \\
\text { oxa, pen, } \\
\text { sxt }\end{array}$ \\
\hline \multirow[t]{2}{*}{$2 / 20 / 13$} & $\begin{array}{l}\text { heavy Staphylococcus aureus } \\
\text { (MRSA) }\end{array}$ & van, gen, tet & $\begin{array}{l}\text { cli, cip, } \\
\text { ery, Ivx, } \\
\text { oxa, pen, } \\
\text { sxt }\end{array}$ \\
\hline & few Morganella morganii & $\begin{array}{l}\text { ami, caz, ipm, mem, tzp, } \\
\text { tob }\end{array}$ & $\begin{array}{l}\text { czn, lvx, } \\
\text { sxt }\end{array}$ \\
\hline $3 / 12 / 13$ & $\begin{array}{l}\text { few Staphylococcus aureus } \\
\text { (MRSA) }\end{array}$ & van, tet, gen & $\begin{array}{l}\text { cli, cip, } \\
\text { ery, Ivx, } \\
\text { oxa, pen, } \\
\text { sxt }\end{array}$ \\
\hline \multirow[t]{2}{*}{$4 / 15 / 13$} & $\begin{array}{l}\text { moderate Staphylococcus } \\
\text { aureus (MRSA) }\end{array}$ & van, tet, gen & $\begin{array}{l}\text { cli, cip, ery, } \\
\text { lvx, oxa, } \\
\text { pen, sxt }\end{array}$ \\
\hline & Enterococcus faecalis & amp, gen, pen, van & None \\
\hline \multirow[b]{2}{*}{$9 / 30 / 13$} & $\begin{array}{l}\text { moderate Morganella } \\
\text { morganii }\end{array}$ & $\begin{array}{l}\text { ami, caz, ipm, mem, tzp, } \\
\text { tob }\end{array}$ & $\begin{array}{l}\text { sxt, Ivx, } \\
\text { czn }\end{array}$ \\
\hline & $\begin{array}{l}\text { heavy Staphylococcus aureus } \\
\text { (MRSA) }\end{array}$ & van, gen & \begin{tabular}{ll}
\multicolumn{2}{l}{ cli, cip, ery, } \\
lvx, oxa, \\
pen, tet, \\
sxt
\end{tabular} \\
\hline $10 / 14 / 13$ & Bacillus species & None & None \\
\hline \multirow[b]{2}{*}{$10 / 7 / 13$} & rare Morganella morganii & $\begin{array}{l}\text { ami, caz, ipm, mem, tzp, } \\
\text { tob }\end{array}$ & $\begin{array}{l}\text { sxt, Ivx, } \\
\text { caz }\end{array}$ \\
\hline & $\begin{array}{l}\text { rare Staphylococcus aureus } \\
\text { (MRSA) }\end{array}$ & van, gen & $\begin{array}{l}\text { cli, cip, } \\
\text { ery, Ivx, } \\
\text { oxa, pen, } \\
\text { tet, sxt }\end{array}$ \\
\hline \multirow{3}{*}{$11 / 20 / 14$} & $\begin{array}{l}\text { few Staphylococcus aureus } \\
\text { (MRSA) }\end{array}$ & van, gen & $\begin{array}{l}\text { cli, cip, } \\
\text { ery, Ivx, } \\
\text { oxa, pen, } \\
\text { tet, sxt }\end{array}$ \\
\hline & $\begin{array}{l}\text { Enterococcus faecalis } \\
\text { (non-VRE) }\end{array}$ & None & None \\
\hline & $\begin{array}{l}\text { heavy Corynebacterium } \\
\text { striatum }\end{array}$ & None & None \\
\hline
\end{tabular}

Table continued

\begin{tabular}{|c|c|c|c|}
\hline \multicolumn{4}{|c|}{ Patient 3} \\
\hline $\begin{array}{l}\text { Date of } \\
\text { cx }\end{array}$ & Culture results & Sensitive & Resistant \\
\hline \multirow{3}{*}{ 9/5/2012 } & $\begin{array}{l}\text { coagulase negative } \\
\text { Staphylococcus }\end{array}$ & cip, gen, Ivx, oxa, sxt, van & $\begin{array}{l}\text { cli, ery, } \\
\text { pen, tet }\end{array}$ \\
\hline & Enterococcus faecalis & amp, gen, pen, van & None \\
\hline & Escherichia coli & $\begin{array}{l}\text { ami, amp, czn, fox, caz, gen, } \\
\text { ipm, Ivx, mem, tzp, tob, sxt }\end{array}$ & None \\
\hline \multirow{2}{*}{$10 / 14 / 12$} & $\begin{array}{l}\text { coagulase negative } \\
\text { Staphylococcus }\end{array}$ & None & None \\
\hline & Escherichia coli & $\begin{array}{l}\text { ami, amp, czn, fox, caz, gen, } \\
\text { ipm, Ivx, mem, tzp, tob, sxt }\end{array}$ & None \\
\hline $12 / 7 / 12$ & $\begin{array}{l}\text { moderate Pseudomonas } \\
\text { aeruginosa }\end{array}$ & $\begin{array}{l}\text { ami, caz, cip, ipm, Ivx, mem, } \\
\text { tob }\end{array}$ & None \\
\hline $12 / 5 / 12$ & $\begin{array}{l}\text { heavy Pseudomonas } \\
\text { aeruginosa }\end{array}$ & $\begin{array}{l}\text { ami, caz, cip, ipm, Ivx, mem, } \\
\text { tob }\end{array}$ & None \\
\hline \multirow{4}{*}{$5 / 23 / 13$} & $\begin{array}{l}\text { moderate Acinetobacter } \\
\text { baumannii }\end{array}$ & ami, ipm, tob, sxt & $\begin{array}{l}\text { caz, lvx, } \\
\text { mem, } \\
\text { tzp }\end{array}$ \\
\hline & light Escherichia coli & $\begin{array}{l}\text { ami, cefazolin, caz, ipm, Ivx, } \\
\text { mem, tob, sxt }\end{array}$ & tzp \\
\hline & light viridans Strep & None & None \\
\hline & light Bacteroides fragilis & None & None \\
\hline \multirow[b]{2}{*}{ 10/24/13 } & $\begin{array}{l}\text { rare coagulase negative } \\
\text { Staphylococcus }\end{array}$ & None & None \\
\hline & Pseudomonas aeruginosa & $\begin{array}{l}\text { ami, cip, Ivx, mem, tob; } \\
\text { intermediate sensitivity to caz, } \\
\text { ipm }\end{array}$ & None \\
\hline $10 / 3 / 13$ & $\begin{array}{l}\text { few Pseudomonas } \\
\text { aeruginosa }\end{array}$ & $\begin{array}{l}\text { ami,caz, cip, ipm, Ivx, mem, } \\
\text { tob }\end{array}$ & None \\
\hline
\end{tabular}

Chronic wounds, such as those implicated in CGVHD, contain a persistently high amount of inflammatory exudate, a milieu that impedes the proliferation of fibroblasts [14]. Similar to ulcerations of other causes (such as venous stasis ulcers, or diabetic foot ulcers), local therapy plays an important role in diminishing local inflammation and promoting wound healing. Ideal dressings are those that control exudate, prevent bacterial proliferation, and absorb excessive wound drainage while preventing the ulcer from drying out. The efficacy of silver impregnated dressings stems from their ability to reduce wound bioburden. The silver impregnated foam dressingsare absorbent and have broad-spectrum antimicrobial activity. They are slightly adherent on one side, facilitating application and allowing the dressing to be left on wounds for up to seven days. It can also be removed nontraumatically during dressing changes and in between dressing changes. The dressing consists of a silicone-based wound contact layer, an absorbent polyurethane foam pad comprised of silver sulfate and activate carbon, and a vaporpermeable waterproof film. Once in contact with wound exudate, silver ions are released. The use of silver in wound management is not new and can be traced to the $18^{\text {th }}$ century for the treatment of skin ulcers. Silver ions target thiol groups on bacterial enzymes causing unraveling; the ions also inhibit bacterial growth, damage the cell wall, and cause structural abnormalities in bacterial nucleic acids. The bactericidal properties of silver have lead to its common use in burn patients and wound dressings. 
Addition of a silver-containing collagen scaffold dressing may assist in replenishing some of the structure, components, and signaling mechanisms needed for wound healing and regeneration[15]. Compression therapy is a critical component to healing most chronic wounds by reversing tissue edema and improving blood and lymphatic flow to the wound bed. The use of self-adherent dressings for compression is useful for these patients because they are easily applied, can be changed frequently and are disposable. Traditional compression stockings are very difficult for these patients because of their restricted range of motion.

While the small number of patients in our case series ( 3 patients total) is a limiting factor, we report the successful treatment of three recalcitrant ulcers from sclerotic GVHD using a combination of silver collagen matrix dressings, silver sponge dressing and compression. All three patients demonstrated wound closure, decreased pain, and increased mobility following 2 to 4 months of therapy. Data on localized treatment of cGHVD ulcers is scare, and no randomized control trials investigating specific dressings or wound care regimens have been performed on patients with CGHVD ulcers. Chronic GVHD ulcers represent the most severe form of cutaneous disease and further knowledge is needed to identify effective treatments.

Funding: This article has no funding sources

Disclosures: The authors have no conflict of interest to declare

\section{References}

1. Bhushan, V. \& Collins, R. H., Jr. Chronic graft-vs-host disease. JAMA : the journal of the American Medical Association. 2003;290(19):2599-603., doi: 10.1001/jama.290.19.2599

2. Martires KJ, Baird K, Steinberg SM, Grkovic L, Joe GO, et al. Sclerotic-type chronic GVHD of the skin: clinical risk factors, laboratory markers, and burden of disease. Blood. 2011;118: 4250-4257. doi: 10.1182/blood-2011-04-350249

3. Linhares YP, Pavletic S, Gale RP. Chronic GVHD: Where are we? Where do we want to be? Will immunomodulatory drugs help? Bone marrow transplantation. 2013;48:203-209. doi: 10.1038/bmt.2012.76.

4. Goldberg, JD, Giralt S. Assessing response of therapy for acute and chronic graft-versus-host disease. Expert Rev Hematol. . 2013;6(1):103107. doi: $10.1586 /$ ehm. 12.65 .

5. Johnson ML, Farmer ER. Graft-versus-host reactions in dermatology. J Am Acad Dermatol. 1998;38(3):369-92.

6. Inamoto Y, Storer BE, Petersdorf EW, Nelson JL, Lee SJ, Carpenter PA, et al. Incidence, risk factors, and outcomes of sclerosis in patients with chronic graft-versus-host disease. Blood. 2013;121(25):5098-103. doi: 10.1182/blood-2012-10-464198.

7. Chavan R, el-Azhary RR. Cutaneous graft-versus-host disease: rationales and treatment options. Dermatol Ther. 2011;24(2):219-28. doi: 10.1111/j.1529-8019.2011.01397.x.

8. Jachiet M, de Masson A, Peffault de Latour R, Rybojad M, Robin M, et al. Skin ulcers related to chronic graft-versus-host disease: clinical findings and associated morbidity. Br J Dermatol. 2014;171(1):63-68 doi: 10.1111/ bjd. 12828

9. Wu PA1, Cowen EW. Cutaneous graft-versus-host disease--clinical considerations and management. Curr Probl Dermatol. 2012;43:101-15. doi: 10.1159/000335270.

10. Kroft EB, Berkhof NJ, van de Kerkhof PC, Gerritsen RM, de Jong EM. Ultraviolet A phototherapy for sclerotic skin diseases: a systematic review. J Am Acad Dermatol. 2008;59(6):1017-30. doi: 10.1016/j.jaad.2008.07.042.

11. Mariotto $A B$, Yabroff KR, ShaoY, Feuer EJ, Brown ML. Projections of the cost of cancer care in the United States: 2010-2020. J Natl Cancer Inst. 2011; 103(2): 117-128. doi: 10.1093/jnci/djq495

12. Lebeaux, D., Ghigo, J. M. \& Beloin, C. Biofilm-related infections: bridging the gap between clinical management and fundamental aspects of recalcitrance toward antibiotics. Microbiol Mol Biol Rev. 2014;78(3):510543. doi: 10.1128/MMBR.00013-14

13. Colsky AS, Kirsner RS, Kerdel FA. Analysis of antibiotic susceptibilities of skin wound flora in hospitalized dermatology patients: the crisis of antibiotic resistance has come to the surface. Arch Dermatol. 1998:134(8):1006-9.

14. Bucalo B, Eaglstein WH, FalangaV. Inhibition of cell proliferation by chronic wound fluid. Wound repair and regeneration : official publication of the Wound Healing Society [and] the European Tissue Repair Society. 1993;1(3):181-186, doi: 10.1046/j.1524-475X.1993.10308.x.

15. Iorio ML, Shuck J, Attinger CE. Wound healing in the upper and lower extremities: a systematic review on the use of acellular dermal matrices. Plast Reconstr Surg. 2012;130(5 Suppl 2):232S-41S. doi: 10.1097/ PRS.0b013e3182615703. 